\title{
Effect of Plant Growth-Promoting Rhizobacteria and Cyanobacteria on Physico-chemical and cooking characteristics of Giza 179 rice grains
}

\author{
Nehal M. Elekhtyar* (D), Mamdouh M.A. Awad-Allah, Abdo A. Zidan
}

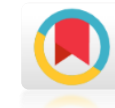

Address:

Rice Research and Training Center, Field Crops Research Institute, Agricultural Research Center, Giza, Egypt

*Corresponding author: Nehal M. Elekhtyar, Nehal RRTC@yahoo.com

Received: 14-08-2021; Accepted: 28-01-2022; Published: 14-02-2022

doi: 202210.21608/ejar.2022.90424.1134

\section{ABSTRACT}

Rice's market worth is mostly determined by its physico-chemical quality, as well as its cooking and eating efficiency. The milling characteristics of Egyptian rice Giza $179 \mathrm{cv}$. are problematic. Through the finest agronomic techniques of rice, we hope to solve this problem. A field experiment has been performed at the Rice Research and Training Center (RRTC), Sakha, Kafrelsheikh, Egypt in the 2019 and 2020 seasons. Plant growth-promoting rhizobacteria (PGPR) and cyanobacteria (blue green algae, BGA) have been used as biofertilizers, evaluating their impact on yield and grain quality. Combining inorganic nitrogen in the form of urea with biofertilizers improved grain yield and physicochemical and cooking characteristics such as milling properties (hulling\%, milling\%, and head rice\%), cooking and eating quality characteristics (gelatinization temperature, gel consistency test, amylose content\%, and kernel elongation\%), physical characteristics (grain length, width, and shape), chemical compositions (nitrogen uptake, protein content, ash content, fat\%, and carbohydrate\%. PGPR and BGA inoculation in combination with $110 \mathrm{Kg} \mathrm{ha}^{-1}$ of $\mathrm{N}$ resulted in the greatest values of these characteristics, except carbohydrate\% and grain shape, with no significant changes in inorganic nitrogen at the recommended rate of $165 \mathrm{Kg} \mathrm{ha}^{-1} \mathrm{of} \mathrm{N}$. Fertilization that contains biofertilizers enriches the Egyptian Giza 179 rice grain's physical, chemical, and cooking qualities.

Keywords: Rice grain quality, PGPR, Cyanobacteria, BGA, Giza 179 cv.

\section{INTRODUCTION}

Rice (Oryza sativa L.), one of the world's most significant crops, with an annual cultivated area of around 1,307,000 ha in Egypt, with an average production rate of $9.59 \mathrm{t} \mathrm{ha-}^{-1}$ (RRTC, 2020). To fulfil the ever-increasing need for food, Egypt's and the world's rising populations require an increase in the production of food crops. Almost all of Egypt's farmers use a lot of chemical fertilizers. They add not less than $480 \mathrm{~kg} \mathrm{ha}^{-1}$ of urea to meet the needs of rice production. This is both costly and environmentally damaging. Plant growth-promoting rhizobacteria (PGPR) impact plant development by generating and releasing secondary metabolites, as well as helping the plant to uptake specific nutrients from the rhizosphere.(Elekhtyar, 2015a). Free-living bacteria extracted from the rhizosphere, PGPR enhances the development of plants when inoculated on seeds or crops, Bacillus and Azospirillium are two bacteria that have been involved with PGPR. Plant growth-promoting rhizobacteria and inorganic nitrogen fertilizer improve germination, seedling health, nitrogen absorption, grain production and grain quality when combined with inorganic nitrogen fertilizers. (Elekhtyar, 2016; Sorour et al., 2018).

As a human food source and a fertilizer in rice fields to fix atmospheric nitrogen, Cyanobacteria enhance the oxygen content and improve the Physico-chemical parameters of the environment and plant (Elekhtyar et al., 2015; Zidan et al., 2015). Rice is one of the most important sources of protein and carbs (Mohammed, 2017). Fertilizers treatments and environmental changes impact the Physico-chemical, cooking and eating characteristics of milled grains (Anjum et al., 2007). Agronomic characteristics such as fertilizers can improve rice grain quality and increase rice grain protein content. Giza 179 is experiencing problems with the milling characteristics. The current study help to solve this difficulty via certain agronomy methods like inoculation to increase cell metabolism therefore health and quality of rice grains (Ceccanti et al., 1994). In this study, biofertilizers are employed to improve the physical, chemical, and cooking attributes of the Egyptian Giza 179 rice cultivar. The purpose of this research is to employ the best rice agronomic methods to solve the milling qualities problem in Egyptian rice Giza 179 cv.

\section{MATERIAL AND METHODS}

Experimental site:

The present research was carried in 2019 and 2020 at the Rice Research and Training Center (RRTC) experimental farm in Sakha, Kafrelsheikh, Egypt, to determine the effects of two microbial inoculations, plant growth-promoting rhizobacteria (PGPR) and Cyanobacteria (Blue green algae, BGA), and their combinations with inorganic nitrogen fertilizers on the yield and grain quality characteristics of the Giza 179 rice cultivar. In a permanent field, urea (46\% nitrogen) was treated in two split doses at a rate of $165 \mathrm{Kg} \mathrm{ha}^{-1}$ of nitrogen. Biofertilization was done with cyanobacteria and Plant-Growth Promoting Rhizobacteria (PGPR). 
Two microbial inoculations were used i.e.:

- Plant growth-promoting rhizobacteria (PGPR) was utilized in a mix of Bacillus subtilis and Azospirillum brasilense as nitrogen fixers at the rate of $2.380 \mathrm{~kg} \mathrm{ha}^{-1}$ of powder inoculation, was top-dressed at transplanting in the permanent field. Inoculation was combined with enough sand to make homogeneous dispersion easier.

- Cyanobacteria (Blue-green algae, BGA) was employed at the rate of $3.570 \mathrm{~kg} \mathrm{ha}^{-1}$ of powder inoculation, was topdressed at transplanting in the permanent field, Inoculation combined with enough sand to make homogeneous dispersion easier.

The biofertilizers were produced by Egypt's Ministry of Agriculture and Land Reclamation's General Organization for Agricultural Equalization Fund. Soil samples were taken from each site at a depth of $30 \mathrm{~cm}$ below the soil surface. Soil analysis methods are clarified by Black et al. (1965). Some of the chemical properties of the soil at the test site are shown in Table 1. Table 1. Soil chemical properties of the experimental sites in 2019 and 2020 seasons.

\begin{tabular}{|c|c|c|}
\hline & 2019 & 2020 \\
\hline \multicolumn{3}{|l|}{ Soluble anions (meq. $\mathrm{L}^{-1}$ ) } \\
\hline $\mathrm{HCO}_{3}{ }^{-}$ & 7.80 & 17.00 \\
\hline $\mathrm{Cl}^{-}$ & 7.20 & 16.90 \\
\hline $\mathrm{SO}_{4}^{--}$ & 3.12 & 2.90 \\
\hline \multicolumn{3}{|l|}{ Soluble Cations (Meq. $\mathrm{L}^{-1}$ ) } \\
\hline$\overline{\mathrm{Ca}^{++}}$ & 9.41 & 8.25 \\
\hline $\mathrm{Mg}^{++}$ & 4.52 & 3.80 \\
\hline $\mathrm{K}^{+}$ & 1.48 & 1.22 \\
\hline $\mathrm{Na}^{++}$ & 12.40 & 13.05 \\
\hline \multicolumn{3}{|l|}{ Availabe micronutrients (ppm) } \\
\hline$\overline{\mathrm{Fe}^{++}}$ & 5.95 & 5.30 \\
\hline $\mathrm{Mn}^{++}$ & 3.30 & 3.10 \\
\hline $\mathrm{Zn}^{++}$ & 1.00 & 1.15 \\
\hline Available $\mathrm{NH}_{4+}\left(\mathrm{mg} \mathrm{kg}^{-1}\right)$ & 14.15 & 13.70 \\
\hline Available $\mathrm{P}\left(\mathrm{mg} \mathrm{kg}^{-1}\right)$ & 11.92 & 12.00 \\
\hline Available $\mathrm{K}\left(\mathrm{mg} \mathrm{kg}^{-1}\right)$ & 375 & 380 \\
\hline $\mathrm{Ec}\left(\mathrm{ds} \cdot \mathrm{m}^{-1}\right)$ & 2.55 & 2.25 \\
\hline $\mathrm{pH}(1: 2.5$ water suspension) & 8.12 & 8.18 \\
\hline Organic Matter (O.M) \% & 1.59 & 1.53 \\
\hline Soil texture & Clayey & Clayey \\
\hline
\end{tabular}

Experimental design and treatments:

We soaked seeds for $24 \mathrm{~h}$, then incubated them for 48 hours to promote early germination. We used $96 \mathrm{~kg} \mathrm{ha}^{-1}$ of seeds. For both seasons, seeds were sown on $10^{\text {th }}$ May. After 30 days from the date of sowing, the seedlings were carefully moved from the nursery and transplanted in a permanent field. The $20 \times 20 \mathrm{~cm}$ spacing was used to physically transplant seedlings into plots measuring $12 \mathrm{~m}^{2}$. The experiment included nine treatments, $\mathrm{T} 1: 165 \mathrm{Kg} \mathrm{ha}^{-1}$ of $\mathrm{N}(165 \mathrm{~N}), \mathrm{T} 2: 110 \mathrm{Kg} \mathrm{ha}^{-1}$ of $\mathrm{N}(110 \mathrm{~N}), \mathrm{T3}$ : $110 \mathrm{~N}+$ PGPR, T4: $110 \mathrm{~N}+$ BGA, T5: $110 \mathrm{~N}+($ PGPR + BGA), T6: PGPR, T7: BGA, T8: PGPR + BGA and T9: Zero fertilizers or inoculations. A Randomized Complete Block Design with four replications in each season was used to set up the experiment. Rice Research and Training Center recommended that the traditional agricultural practices of cultivating rice be followed (RRTC 2020).

Studied characters and data collection:

- Milling characteristics (hulling, milling, and head rice percentages) were determined using the Satake testing equipment according to Adair (1952).

- Cooking and eating quality characteristics were estimated such as Gelatinization temperature (Little et al., 1958). Gel consistency test (Cagampang et al., 1973) Amylose content (Juliano, 1971) and Kernel Elongation (Azeez and Shafi, 1966).

- Chemical compositions were determined: nitrogen concentration, N\% (Hafez and Mikkelson, 1981). ash content and fat content (A.O.A.C., 1990). nitrogen uptake, Protein content and Carbohydrate were calculated as follow:

Nitrogen uptake in grains $=\mathrm{N} \% \mathrm{x}$ grain dry weight

Protein content $(\%)=\mathrm{N} \% \times 5.95$

Carbohydrate $(\%)=100 \%$ - (moisture $\%+$ fat $\%+$ ash $\%+$ protein $\%)$

- Physical characteristics (Grain length, width and shape was estimated according to Khush et al. (1979).

- Grain yield, harvested dry grains were weighted and adjusted to a moisture level of $14 \%$, and then the yield was determined

Statistical analysis:

All collected data were statistically analyzed according to the technique of analysis of variance as a Randomized Complete Block Design (RCBD) analysis for the two sites and the Duncan's Multiple Range Test (Duncan, 1955) was used to test the difference among the treatment means as published by (Gomez and Gomez, 1984). All statistical analysis was performed using analysis of variance technique using "MSTAT-C" computer software package (Elekhtyar, 2018).

RESULTS 
Data in Table (2) Show that bio and inorganic nitrogen fertilizers had an impact on milling characteristics such as hulling, milling, and head rice percentage of the Giza 179 rice cultivar in 2019 and 2020 seasons. The use of both bio and inorganic nitrogen fertilizers significantly improved milling characteristics than the zero fertilizers treatment, except PGPR alone on hulling\% in the two seasons. The combination of $110 \mathrm{~N}+(\mathrm{PGPR}+\mathrm{BGA})$ resulted in a substantial increase in milling characteristics compared with the recommended rate of inorganic nitrogen $(165 \mathrm{~N})$ and all other treatments. There were no significant differences among $110 \mathrm{~N}+$ PGPR, $110 \mathrm{~N}+$ BGA and $165 \mathrm{~N}$ in milling\% and head rice\% in both seasons.

Table 2. Rice cultivar Giza 179's grain hulling, milling and head rice percentage in 2019 and 2020 seasons as influenced by biofertilizers, inorganic nitrogen and their combinations.

\begin{tabular}{|l|c|c|c|c|c|c|}
\hline \multirow{2}{*}{ Treatment } & \multicolumn{2}{|c|}{ Hulling\% } & \multicolumn{2}{c|}{ Milling\% } & \multicolumn{2}{c|}{ Head rice\% } \\
\cline { 2 - 7 } & $\mathbf{2 0 1 9}$ & $\mathbf{2 0 2 0}$ & $\mathbf{2 0 1 9}$ & $\mathbf{2 0 2 0}$ & $\mathbf{2 0 1 9}$ & $\mathbf{2 0 2 0}$ \\
\hline $\mathbf{1 6 5} \mathbf{N}$ & $79.23 \mathrm{c}$ & $78.73 \mathrm{~b}$ & $71.02 \mathrm{~b}$ & $70.09 \mathrm{bc}$ & $65.83 \mathrm{ab}$ & $65.36 \mathrm{~b}$ \\
\hline $\mathbf{1 1 0} \mathbf{N}$ & $78.45 \mathrm{de}$ & $77.41 \mathrm{~cd}$ & $70.48 \mathrm{c}$ & $69.91 \mathrm{c}$ & $65.25 \mathrm{c}$ & $65.07 \mathrm{c}$ \\
\hline $\mathbf{1 1 0} \mathbf{N}+$ PGPR & $79.58 \mathrm{~b}$ & $79.05 \mathrm{~b}$ & $71.24 \mathrm{~b}$ & $70.71 \mathrm{ab}$ & $65.84 \mathrm{ab}$ & $65.28 \mathrm{bc}$ \\
\hline $\mathbf{1 1 0} \mathbf{N}+\mathbf{B G A}$ & $78.75 \mathrm{~d}$ & $77.57 \mathrm{c}$ & $70.83 \mathrm{bc}$ & $70.19 \mathrm{~b}$ & $65.75 \mathrm{~b}$ & $65.24 \mathrm{bc}$ \\
\hline $\mathbf{1 1 0} \mathbf{N}+\mathbf{( P G P R}+\mathbf{B G A})$ & $80.97 \mathrm{a}$ & $80.24 \mathrm{a}$ & $71.74 \mathrm{a}$ & $71.14 \mathrm{a}$ & $66.05 \mathrm{a}$ & $65.67 \mathrm{a}$ \\
\hline PGPR & $77.36 \mathrm{~g}$ & $76.74 \mathrm{~d}$ & $69.57 \mathrm{e}$ & $68.81 \mathrm{e}$ & $64.48 \mathrm{e}$ & $64.11 \mathrm{e}$ \\
\hline BGA & $77.81 \mathrm{f}$ & $76.96 \mathrm{c}-\mathrm{e}$ & $70.23 \mathrm{~d}$ & $69.28 \mathrm{~d}$ & $64.44 \mathrm{e}$ & $64.05 \mathrm{e}$ \\
\hline PGPR + BGA & $78.04 \mathrm{e}$ & $77.55 \mathrm{c}$ & $70.29 \mathrm{~d}$ & $69.84 \mathrm{c}$ & $64.82 \mathrm{~d}$ & $64.45 \mathrm{~d}$ \\
\hline Zero fertilizers & $77.13 \mathrm{~h}$ & $76.52 \mathrm{e}$ & $68.32 \mathrm{f}$ & $67.74 \mathrm{f}$ & $63.61 \mathrm{f}$ & $63.26 \mathrm{f}$ \\
\hline F. test & $* *$ & $* *$ & $* *$ & $* *$ & $* *$ & $* *$ \\
\hline
\end{tabular}

$165 \mathrm{~N}=165 \mathrm{~kg} \mathrm{ha}^{-1}$ of $\mathrm{N}$ and $110 \mathrm{~N}=110 \mathrm{~kg} \mathrm{ha}^{-1}$ of $\mathrm{N} ;{ }^{* *}$ indicate $\mathrm{P}<0.01$

According to Table (3) bio and inorganic nitrogen fertilizers had a significant effect on cooking and eating quality features such as gelatinization temperature (GT), gel consistency (GC), amylose content\%, and kernel elongation\% in 2019 and 2020 seasons. Treatments containing inorganic nitrogen led to a significant increase in cooking and eating quality features compared with zero fertilizers and other treatments in the two seasons. The highest values of these traits were obtained from $110 \mathrm{~N}+($ PGPR + BGA), while the lowest ones were obtained from zero fertilizers. The $110 \mathrm{~N}+\mathrm{PGPR}$ and $110 \mathrm{~N}+(\mathrm{PGPR}+$ $B G A)$ were statistically at par in amylose content, and kernel elongation\% in both seasons and GT and GC in one season. Application of BGA and PGPR+ BGA was superior to zero fertilizers treatment in GC and kernel elongation\% in the two seasons. Bacterial inoculation PGPR or BGA alone did not different than zero fertilizers treatment in GT and amylose content in the two seasons.

Table 3. Rice cultivar Giza 179's grain gelatinization temperature (GT), gel consistency (GC), amylose content and kernel Elongation percentage in 2019 and 2020 seasons as influenced by biofertilizers, inorganic nitrogen and their combinations.

\begin{tabular}{|l|c|c|c|c|c|c|c|c|}
\hline \multirow{2}{*}{ Treatments } & \multicolumn{2}{|c|}{$\begin{array}{c}\text { Gelatinization } \\
\text { temperature (GT) }\end{array}$} & \multicolumn{2}{c|}{$\begin{array}{c}\text { Gel consistency } \\
(\mathbf{m m})\end{array}$} & \multicolumn{2}{c|}{$\begin{array}{c}\text { Amylose } \\
\text { (\%) }\end{array}$} & \multicolumn{2}{c|}{$\begin{array}{c}\text { Kernel Elongation } \\
\text { (\%) }\end{array}$} \\
\cline { 2 - 10 } & $\mathbf{2 0 1 9}$ & $\mathbf{2 0 2 0}$ & $\mathbf{2 0 1 9}$ & $\mathbf{2 0 2 0}$ & $\mathbf{2 0 1 9}$ & $\mathbf{2 0 2 0}$ & $\mathbf{2 0 1 9}$ & $\mathbf{2 0 2 0}$ \\
\hline $\mathbf{1 6 5} \mathbf{N}$ & $5.750 \mathrm{~b}$ & $5.750 \mathrm{ab}$ & $95.53 \mathrm{ab}$ & $93.91 \mathrm{~b}$ & $18.95 \mathrm{ab}$ & $18.88 \mathrm{ab}$ & $65.56 \mathrm{~b}$ & $64.42 \mathrm{~b}$ \\
\hline $\mathbf{1 1 0} \mathbf{N}$ & $5.375 \mathrm{c}$ & $5.375 \mathrm{~b}-\mathrm{d}$ & $91.81 \mathrm{c}$ & $90.34 \mathrm{c}$ & $18.50 \mathrm{~b}$ & $17.87 \mathrm{c}$ & $59.50 \mathrm{c}$ & $58.50 \mathrm{~d}$ \\
\hline $\mathbf{1 1 0} \mathbf{N}+$ PGPR & $5.875 \mathrm{~b}$ & $5.750 \mathrm{ab}$ & $95.47 \mathrm{ab}$ & $94.09 \mathrm{~b}$ & $19.04 \mathrm{a}$ & $19.02 \mathrm{ab}$ & $66.37 \mathrm{ab}$ & $65.37 \mathrm{ab}$ \\
\hline $\mathbf{1 1 0} \mathbf{N}+$ BGA & $5.625 \mathrm{bc}$ & $5.563 \mathrm{bc}$ & $94.38 \mathrm{~b}$ & $93.34 \mathrm{~b}$ & $18.83 \mathrm{ab}$ & $18.45 \mathrm{~b}$ & $62.98 \mathrm{~b}$ & $61.85 \mathrm{c}$ \\
\hline $\mathbf{1 1 0} \mathbf{N}+$ (PGPR + BGA) & $6.250 \mathrm{a}$ & $6.125 \mathrm{a}$ & $97.44 \mathrm{a}$ & $96.28 \mathrm{a}$ & $19.32 \mathrm{a}$ & $19.34 \mathrm{a}$ & $69.49 \mathrm{a}$ & $68.30 \mathrm{a}$ \\
\hline PGPR & $5.188 \mathrm{~d}$ & $5.188 \mathrm{~cd}$ & $81.06 \mathrm{f}$ & $79.53 \mathrm{f}$ & $17.39 \mathrm{~cd}$ & $17.19 \mathrm{e}$ & $52.02 \mathrm{de}$ & $51.28 \mathrm{ef}$ \\
\hline BGA & $5.250 \mathrm{~d}$ & $5.188 \mathrm{~cd}$ & $83.91 \mathrm{e}$ & $83.22 \mathrm{e}$ & $17.36 \mathrm{~cd}$ & $17.17 \mathrm{e}$ & $54.79 \mathrm{~d}$ & $53.85 \mathrm{e}$ \\
\hline PGPR + BGA & $5.125 \mathrm{~d}$ & $5.250 \mathrm{c}$ & $88.59 \mathrm{~d}$ & $87.22 \mathrm{~d}$ & $17.84 \mathrm{c}$ & $17.37 \mathrm{~d}$ & $58.60 \mathrm{c}$ & $57.54 \mathrm{~d}$ \\
\hline Zero fertilizers & $5.188 \mathrm{~d}$ & $5.000 \mathrm{~d}$ & $76.88 \mathrm{~g}$ & $75.34 \mathrm{~g}$ & $17.34 \mathrm{~d}$ & $17.11 \mathrm{e}$ & $49.69 \mathrm{e}$ & $49.44 \mathrm{f}$ \\
\hline F. test & $* *$ & $* *$ & $* *$ & $* *$ & $* *$ & $* *$ & $* *$ & $* *$ \\
\hline
\end{tabular}

$165 \mathrm{~N}=165 \mathrm{~kg} \mathrm{ha}^{-1}$ of $\mathrm{N}$ and $110 \mathrm{~N}=110 \mathrm{~kg} \mathrm{ha}^{-1}$ of $\mathrm{N} ;{ }^{* *}$ indicate $\mathrm{P}<0.01$

Giza 179 rice cultivar's chemical compositions were significantly affected by bio and inorganic nitrogen fertilizers in the 2019 and 2020 seasons Tables ( 4 and 5). Application inorganic nitrogen alone or with biofertilizers inoculation resulted in a significant increase in nitrogen uptake, protein content and ash content compared with zero fertilizers treatment in the two seasons. The inverse was true in carbohydrate content. Mixed inoculation PGPR+BGA substantially increased all chemical compositions than zero fertilizers treatment. Application of $110 \mathrm{~N}+(\mathrm{PGPR}+\mathrm{BGA})$ recorded the maximum values of nitrogen 
uptake, protein content and ash content and the minimum value of carbohydrate content in both seasons. Zero fertilizers treatment produced the highest percentage of carbohydrate in grains in the two seasons.

Table 4. Rice cultivar Giza 179's grain nitrogen uptake and protein content in 2019 and 2020 seasons as influenced by biofertilizers, inorganic nitrogen and their combinations.

\begin{tabular}{|l|c|c|c|c|}
\hline \multirow{2}{*}{ Treatments } & \multicolumn{2}{|c|}{$\begin{array}{c}\text { N uptake in grains } \\
\text { (Kg ha-1) }\end{array}$} & \multicolumn{2}{c|}{$\begin{array}{c}\text { Protein } \\
\text { (\%) }\end{array}$} \\
\cline { 2 - 5 } $\mathbf{1 6 5} \mathbf{N}$ & $\mathbf{2 0 1 9}$ & $\mathbf{2 0 2 0}$ & $\mathbf{2 0 1 9}$ & $6.114 \mathrm{bc}$ \\
\hline $\mathbf{1 1 0} \mathbf{N}$ & $122.7 \mathrm{~b}$ & $126.3 \mathrm{~b}$ & $6.586 \mathrm{ab}$ & $5.940 \mathrm{c}$ \\
\hline $\mathbf{1 1 0} \mathbf{N}+$ PGPR & $115.36 \mathrm{bc}$ & $118.79 \mathrm{c}$ & $6.370 \mathrm{~b}$ & $6.265 \mathrm{ab}$ \\
\hline $\mathbf{1 1 0} \mathbf{N}+$ BGA & $126.33 \mathrm{ab}$ & $125.73 \mathrm{~b}$ & $6.582 \mathrm{ab}$ & $5.969 \mathrm{c}$ \\
\hline $\mathbf{1 1 0} \mathbf{N}+$ (PGPR + BGA) & $119.11 \mathrm{~b}$ & $120.09 \mathrm{bc}$ & $6.482 \mathrm{~b}$ & $6.354 \mathrm{a}$ \\
\hline PGPR & $130.11 \mathrm{a}$ & $128.91 \mathrm{a}$ & $6.873 \mathrm{a}$ & $5.387 \mathrm{e}$ \\
\hline BGA & $111.65 \mathrm{c}$ & $109.77 \mathrm{~cd}$ & $5.645 \mathrm{~cd}$ & $5.415 \mathrm{e}$ \\
\hline PGPR + BGA & $110.34 \mathrm{c}$ & $111.41 \mathrm{~cd}$ & $5.642 \mathrm{~cd}$ & $5.616 \mathrm{~d}$ \\
\hline Zero fertilizers & $114.91 \mathrm{bc}$ & $116.11 \mathrm{c}$ & $5.842 \mathrm{c}$ & $5.094 \mathrm{f}$ \\
\hline F. test & $107.44 \mathrm{~d}$ & $102.06 \mathrm{~d}$ & $5.334 \mathrm{~d}$ & $*$ \\
\hline
\end{tabular}

$165 \mathrm{~N}=165 \mathrm{~kg} \mathrm{ha}^{-1}$ of $\mathrm{N}$ and $110 \mathrm{~N}=110 \mathrm{~kg} \mathrm{ha}^{-1}$ of $\mathrm{N} ;{ }^{* *}$ indicate $\mathrm{P}<0.01$

Table 5. Rice cultivar Giza 179's grain ash, fat and carbohydrate percentage in 2019 and 2020 seasons as influenced by biofertilizers, inorganic nitrogen and their combinations.

\begin{tabular}{|l|c|c|c|c|c|c|}
\hline \multirow{2}{*}{ Treatments } & \multicolumn{2}{|c|}{ Ash (\%) } & \multicolumn{2}{c|}{ Fat (\%) } & \multicolumn{2}{c|}{ Carbohydrate (\%) } \\
\cline { 2 - 7 } & $\mathbf{2 0 1 9}$ & $\mathbf{2 0 2 0}$ & $\mathbf{2 0 1 9}$ & $\mathbf{2 0 2 0}$ & $\mathbf{2 0 1 9}$ & $\mathbf{2 0 2 0}$ \\
\hline $\mathbf{1 6 5} \mathbf{N}$ & $0.674 \mathrm{a}$ & $0.672 \mathrm{a}$ & $1.174 \mathrm{~b}$ & $1.183 \mathrm{a}$ & $77.57 \mathrm{~cd}$ & $78.03 \mathrm{~cd}$ \\
\hline $\mathbf{1 1 0} \mathbf{N}$ & $0.666 \mathrm{~b}$ & $0.660 \mathrm{~b}$ & $1.161 \mathrm{bc}$ & $1.157 \mathrm{~b}$ & $77.80 \mathrm{c}$ & $78.24 \mathrm{c}$ \\
\hline $\mathbf{1 1 0} \mathbf{N}+$ PGPR & $0.678 \mathrm{a}$ & $0.673 \mathrm{a}$ & $1.177 \mathrm{~b}$ & $1.179 \mathrm{ab}$ & $\mathbf{7 7 . 5 6 \mathrm { cd }}$ & $77.88 \mathrm{~d}$ \\
\hline $\mathbf{1 1 0} \mathbf{N}+$ BGA & $0.671 \mathrm{a}$ & $0.668 \mathrm{ab}$ & $1.164 \mathrm{bc}$ & $1.161 \mathrm{~b}$ & $77.68 \mathrm{c}$ & $78.20 \mathrm{c}$ \\
\hline $\mathbf{1 1 0} \mathbf{N}+$ (PGPR + BGA) & $0.681 \mathrm{a}$ & $0.678 \mathrm{a}$ & $1.211 \mathrm{a}$ & $1.189 \mathrm{a}$ & $77.25 \mathrm{~d}$ & $77.78 \mathrm{~d}$ \\
\hline PGPR & $0.654 \mathrm{bc}$ & $0.653 \mathrm{bc}$ & $1.149 \mathrm{~cd}$ & $1.153 \mathrm{~b}$ & $78.55 \mathrm{ab}$ & $78.81 \mathrm{ab}$ \\
\hline BGA & $0.659 \mathrm{~b}$ & $0.651 \mathrm{bc}$ & $1.153 \mathrm{c}$ & $1.163 \mathrm{~b}$ & $78.55 \mathrm{ab}$ & $78.77 \mathrm{ab}$ \\
\hline PGPR + BGA & $0.661 \mathrm{~b}$ & $0.658 \mathrm{~b}$ & $1.157 \mathrm{c}$ & $1.148 \mathrm{bc}$ & $78.34 \mathrm{~b}$ & $78.58 \mathrm{~b}$ \\
\hline Zero fertilizers & $0.640 \mathrm{c}$ & $0.648 \mathrm{c}$ & $1.144 \mathrm{~d}$ & $1.141 \mathrm{c}$ & $78.87 \mathrm{a}$ & $79.12 \mathrm{a}$ \\
\hline F. test & $*$ & $*$ & $* *$ & $*$ & $* *$ & $* *$ \\
\hline
\end{tabular}

$165 \mathrm{~N}=165 \mathrm{~kg} \mathrm{ha}^{-1}$ of $\mathrm{N}$ and $110 \mathrm{~N}=110 \mathrm{~kg} \mathrm{ha}^{-1}$ of $\mathrm{N} ;{ }^{*}$ and ${ }^{* *}$ indicate $\mathrm{P}<0.05$ and $\mathrm{P}<0.01$ respectively

As shown in Table (6), bio and inorganic nitrogen fertilizers had an impact on the physical characteristics of Giza 179 rice in the 2019 and 2020 seasons. Application of inorganic nitrogen fertilizer alone or with biofertilizer inoculation significantly increased grain length and width compared to no inoculation or fertilizer treatment. In both seasons, the application of 110 $\mathrm{N}+(\mathrm{PGPR}+\mathrm{BGA})$ resulted in longer and thicker grains. The inoculation alone had no significant effect on grain length and width other than zero fertilizer treatment. However, the control treatment recorded the highest value of grain shape, while the $110 \mathrm{~N}+($ PGPR + BGA) treatment recorded the lowest one in both seasons. 
Table 6. Rice cultivar Giza 179's grain length, width, and shape in 2019 and 2020 seasons as influenced by biofertilizers, inorganic nitrogen and their combinations.

\begin{tabular}{|l|c|c|c|c|c|c|}
\hline \multirow{2}{*}{ Treatments } & \multicolumn{2}{|c|}{$\begin{array}{c}\text { Grain length “L” } \\
(\mathbf{m m})\end{array}$} & \multicolumn{2}{c|}{$\begin{array}{c}\text { Grain width “W” } \\
\text { (mm) }\end{array}$} & \multicolumn{2}{c|}{ Grain shape (L/W) ratio } \\
\cline { 2 - 8 } & $\mathbf{2 0 1 9}$ & $\mathbf{2 0 2 0}$ & $\mathbf{2 0 1 9}$ & $\mathbf{2 0 2 0}$ & $\mathbf{2 0 1 9}$ & $\mathbf{2 0 2 0}$ \\
\hline $\mathbf{1 6 5} \mathbf{N}$ & $5.87 \mathrm{ab}$ & $5.83 \mathrm{ab}$ & $2.81 \mathrm{~b}$ & $2.83 \mathrm{a}$ & $2.09 \mathrm{~b}$ & $2.06 \mathrm{bc}$ \\
\hline $\mathbf{1 1 0} \mathbf{N}$ & $5.77 \mathrm{c}$ & $5.68 \mathrm{c}$ & $2.69 \mathrm{c}$ & $2.71 \mathrm{~b}$ & $2.14 \mathrm{ab}$ & $2.10 \mathrm{~b}$ \\
\hline $\mathbf{1 1 0} \mathbf{N}+$ PGPR & $5.87 \mathrm{ab}$ & $5.79 \mathrm{~b}$ & $2.89 \mathrm{~b}$ & $2.79 \mathrm{ab}$ & $2.03 \mathrm{c}$ & $2.08 \mathrm{c}$ \\
\hline $\mathbf{1 1 0} \mathbf{N}+$ BGA & $5.81 \mathrm{~b}$ & $5.77 \mathrm{c}$ & $2.74 \mathrm{c}$ & $2.77 \mathrm{ab}$ & $2.12 \mathrm{ab}$ & $2.08 \mathrm{c}$ \\
\hline $\mathbf{1 1 0} \mathbf{N}+$ (PGPR + BGA) & $5.93 \mathrm{a}$ & $5.88 \mathrm{a}$ & $2.96 \mathrm{a}$ & $2.86 \mathrm{a}$ & $2.00 \mathrm{c}$ & $2.06 \mathrm{bc}$ \\
\hline PGPR & $5.67 \mathrm{~d}$ & $5.64 \mathrm{~cd}$ & $2.57 \mathrm{~d}$ & $2.53 \mathrm{c}$ & $2.21 \mathrm{a}$ & $2.23 \mathrm{ab}$ \\
\hline BGA & $5.69 \mathrm{~cd}$ & $5.67 \mathrm{~cd}$ & $2.61 \mathrm{~cd}$ & $2.66 \mathrm{bc}$ & $2.18 \mathrm{ab}$ & $2.13 \mathrm{~b}$ \\
\hline PGPR + BGA & $5.71 \mathrm{~cd}$ & $5.66 \mathrm{~cd}$ & $2.68 \mathrm{c}$ & $2.68 \mathrm{~b}$ & $2.13 \mathrm{ab}$ & $2.11 \mathrm{~b}$ \\
\hline Zero fertilizers & $5.64 \mathrm{~d}$ & $5.61 \mathrm{~d}$ & $2.51 \mathrm{~d}$ & $2.44 \mathrm{~d}$ & $2.25 \mathrm{a}$ & $2.30 \mathrm{a}$ \\
\hline F. test & $* *$ & $* *$ & $* *$ & $* *$ & $*$ & $*$ \\
\hline
\end{tabular}

$165 \mathrm{~N}=165 \mathrm{~kg} \mathrm{ha}^{-1}$ of $\mathrm{N}$ and $110 \mathrm{~N}=110 \mathrm{~kg} \mathrm{ha}^{-1}$ of $\mathrm{N}$; and ** indicate $\mathrm{P}<0.05$ and $\mathrm{P}<0.01$ respectively

Giza 179 rice has an impact on Giza 179 rice grain production in 2019 and 2020, as shown in Figure 1. It was recorded that the grain production was considerably higher when using $110 \mathrm{~N}$, including a mix of PGPR and BGA, followed by $110 \mathrm{~N}$ with PGPR or $110 \mathrm{~N}$ with BGA, or using inorganic nitrogen at the recommended rate of $165 \mathrm{~N}$ alone. Zero fertilizer treatment produced the lowest yield of rice grain in the two seasons.

\section{$\square$ Grain yield (2019 season)}

$\square$ Grain yield (2020 season)

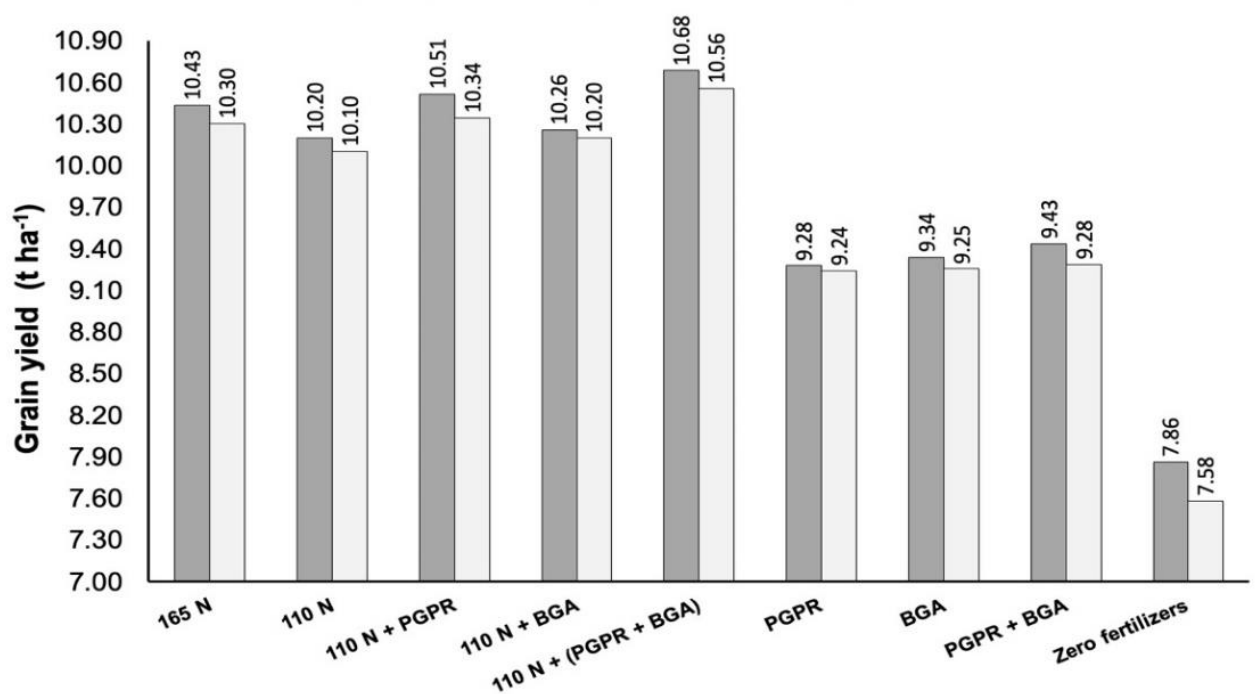

Fig. 1. Rice cultivar Giza 179's grain yield in 2019 and 2020 seasons as influenced by biofertilizers, inorganic nitrogen and their combinations.

\section{DISCUSSION}

This study indicated that combining $110 \mathrm{Kg} \mathrm{ha}^{-1}$ of $\mathrm{N}(110 \mathrm{~N})$ with plant growth rhizobacteria (PGPR) and Cyanobacteria (BGA) considerably improved most of the investigated traits, especially milling traits than the recommended rate of $165 \mathrm{Kg} \mathrm{N} \mathrm{ha}^{-1}$.

To improve milling characteristics, a mix of chemical and biological techniques can be used. In addition, PGPR and Cyanobacteria may modify the cell structure by bacteria or release the intake of nutrients from the soil and environment (Elekhtyar, 2015b). When PGPR avoids the damaging effects of plant pathogens on plants by producing the natural resistance of the host, plant growth occurs as a result. They can fix nitrogen, mineralize and release other nutrients while sequestering iron, cytokinins, and gibberellins. They can also reduce the levels of ethylene concentration by converting auxin into indole acetic acid (IAA), gibberellic acid (GA), cytokinins, and ABA in rice roots. They may Improve capacity to generate antagonistic antibacterial agents, B1-3-glucanase; and improved drought and other stress tolerance by generating water-soluble vitamins 
niacin, thiamine, riboflavin, biotin, and pantothenic acid are some of the benefits (Kaushal et al., 2013; Wissa et al., 2016). As a result, create a healthy rice grain with great milling properties.

The use of PGPR and Cyanobacteria as inoculation improved the cooking and eating quality of Giza 179 rice. Microorganisms have positive impacts on the cell growth and development of a plant (Ashrafuzzaman et al., 2009; Elekhtyar et al., 2016). According to (Goswami et al., 2016; Mazid and Khan, 2017), the rise in cooking and eating quality may be attributed to an increase in microbial activity by these microorganisms that enhances the availability of nutrients for the plants (Pan et al., 2013). Rice grain shape and amylose concentration also impact kernel elongation (Singh et al., 2005) and (Danbaba et al., 2011).

When it comes to nutrient absorption from soil, grain cell chemical composition is crucial. Due to the combination of chemical and biological techniques that can favorably increase cell metabolism (Elekhtyar, 2011), by accessing the nutrients through plasmodesmata where it can be utilized in cell metabolism (Oosterhuis and Weir, 2010). The larger protein content is seen in grains with better nitrogen uptake and higher dry weight of grain. Azospirillum and Bacillus as PGPR may enhance rice biomass, root length, and NPK absorption (Kumar and Dangar, 2013; Elekhtyar et al., 2021). Germination, protein and amino acids, vitamins and nitrogen as well as other necessary components can be increased by 20 to 30 percent by increasing the number of microbes (Sorour et al., 2018; Mikael et al., 2021). Many types of cell wall components can be improved by microorganisms using enzymes such as enzymes that break down protein into amino acids (Lugtenberg et al., 2017). When it comes to rice grains, ash content plays a crucial function in the release of critical minerals (Bhat and Sridhar, 2008).

Maybe a mix of chemical and biological approaches might improve physical characteristics. These microbial interactions have a significant impact on the physical characteristics of rice grains, which are key cooking and eating features (Mckenzie and Ruther, 1983). Energy metabolism, phytohormone synthesis, and cell wall expansion are all activities that stimulate cell development. (Elekhtyar et al., 2017; Wu et al., 2018).

The combination of chemical and biological methods can positively increase the grain yield. The inoculation of PGPR (Azospirillum and Bacillus) and Cyanobacteria as algae in rice plants improved grain yield (Elekhtyar, 2011). Subsequently, they act as biofertilizers and antagonistic agents to save synthetic chemical fertilizers (Kumar and Dangar, 2013). Some microbes can produce enzymes such as cellulases, chitinases, $\beta-1-3$ glucanases, lipases, and proteases (Lugtenberg et al., 2017). This study also indicated that the bacteria and algae may be responsible for the higher rice yield in part by producing growth ingredients and vitamins. This shows that microbe-treated rice has had the best yield of rice grains (Saadatnia and Riahi, 2009; El-Hefny, 2016).

\section{CONCLUSION}

Recent research has shown that combining inorganic nitrogen and biofertilizers increased grain production as well as physicochemical and cooking properties such as milling and cooking quality characteristics, as well as physical characteristics and chemical compositions. Cyanobacteria and PGPR (Bacillus subtilis and Azospirillum brasilense) combined with $110 \mathrm{Kg}$ ha${ }^{1}$ of $\mathrm{N}$ produced the highest values of these characters, with no significant differences between them and those produced by inorganic nitrogen alone at the recommended rate of $165 \mathrm{Kg} \mathrm{ha}^{-1}$ of $\mathrm{N}$.

\section{REFERENCES}

A.O.A.C Association of Official Analytical Chemists (1990). Official methods of analysis Association of Official Analytical Chemists. Washington.D.C.,USA .

Adair, C. R. (1952). The Mcgill miller method for determining the milling quality of small samples of rice. Rice J, 55(2), 21-23.

Anjum, F. M., Pasha, I., Bugti, M. A., \& Butt, M. S. (2007). Mineral composition of different rice varieties and their milling fractions. Pakistan Journal of Agricultural Sciences 44(2), 332-336.

Ashrafuzzaman, M., Hossen, F. A., Ismail, M. R., Hoque, A., Islam, M. Z., Shahidullah, S. M., \& Meon, S. (2009). Efficiency of plant growth-promoting rhizobacteria (PGPR) for the enhancement of rice growth. African Journal of Biotechnology, 8(7).

Azeez, M.A., \& Shafi, M. (1966). Quality in Rice. Department of Agric, West Pakistan Technology Bulletin. No. 13 pp. 50.

Bhat, R., \& Sridhar, K. R. (2008). Nutritional quality evaluation of electron beam-irradiated lotus (Nelumbo nucifera) seeds. Food Chemistry, 107(1), 174-184.

Black, C. A. (1965). Method of soil analysis part 2. Chemical and Microbiological Properties, 9, 1387-1388.

Cagampang, G. B., Perez, C. M., \& Juliano, B. O. (1973). A gel consistency test for eating quality of rice. Journal of the Science of Food and Agriculture, 24(12), 1589-1594.

Ceccanti, B., Pezzarossa, B., Gallardo-Lancho, F. J., \& Masciandaro, G. (1993). Biotests as markers of soil utilization and fertility. Geomicrobiology Journal, 11(3-4), 309-316.

Danbaba, N., Anounye, J. C., Gana, A. S., Abo, M. E., \& Ukwungwu, M. N. (2011). Grain quality characteristics of Ofada rice (Oryza sativa L.): Cooking and eating quality. International Food Research Journal,18,629-634.

Duncan, D. B. (1955). Multiple Range and Multiple F. Test. Biometrics,11,1-42.

Elekhtyar, N. M. (2011). Effect of bio and mineral nitrogen fertilizer on growth, yield and chemical composition of rice (Doctoral dissertation, Ph. D. Thesis, Fac. Agric., Kafrelsheikh Univ., Egypt).

Elekhtyar, N. M. (2015a). Efficiency of Pseudomonas fluorescens as plant growth-promoting rhizobacteria (PGPR) for the enhancement of seedling vigor, nitrogen uptake, yield and its attributes of rice (Oryza sativa L.). International Journal of the Science Research Agricultural Sciences, 2, 57-67. 
Elekhtyar, N. M. (2015b). Impact of three strains of Bacillus as bio NPK fertilizers and three levels of mineral NPK fertilizers on growth, chemical compositions and yield of Sakha 106 rice cultivar. International Journal of ChemTech Research, 8(4), 2150-2156.

Elekhtyar, N. M. (2016). Influence of different plant growth-promoting rhizobacteria (PGPR) strains on rice promising line. Proc. of the sixth field crops Con., FCRI, Agricultural, Egypt, 6, 327-335.

Elekhtyar, N.M. (2018). Statistical Analysis of Experiments Using MSTAT-C Computer Software. Academy of Scientific Research and Technology (ASRT), Egypt. No.: 3486/2018, ISBN: 978-977-268-723-7 (Arabic Edition).

Elekhtyar, N. M., Elkhoby, W. M., \& Zidan, A. A. (2015). Prospects of using rhizobium as supplements for mineral nitrogen fertilizer on rice production in Egypt. Journal of Agricultural Research. Kafr El-Sheikh Univ, 41(3), 875-884.

Elekhtyar, N. M., Elsharnobi, D. E., \& El-Mowafi, H. F. (2021). Evaluation of New Egyptian Japonica Green Super Rice Varieties Under Fertilization and Plant Spacing. Journal of Plant Production, 12(9), 1015-1019.

Elekhtyar, N. M., Metwally, T. F., \& Nour El-Din, M. (2016, March). Evaluation of bio-NPK and compost tea on seedling vigor and yield of rice. In Proceedings of 1st International Conference of Applied Microbiology, 1, 8-20.

Elekhtyar, N. M., Mikhael, B. B., \& Wissa, M. T. (2017). Utilization of compost and compost tea for improving Egyptian hybrid rice one cultivar. Journal of Sustainable Agricultural Sciences, 43(3), 141-149.

El-Hefny A. S. (2016). Economic threshold and economic injury levels for rice stem borer, using simulated white heads in rice. Egyptian Journal of Agricultural Research, 94(2),353-364.

Gomez, K. A., \& Gomez, A. A. (1984). Statistical procedures for agricultural research. John Wiley \& Sons.

Goswami, M., Bhattacharyya, P., Ghosh, A., Das, B., Bhattacharjee, S., Mahanty, T., et al. (2016). Biofertilizers: a potential approach for sustainable agriculture development. Environmental Science Pollution Research, 24(4):3315-35.

Hafez, A. A., \& Mikkelsen, D. S. (1981). Colorimetric determination of nitrogen for evaluating the nutritional status of rice. Communications in Soil Science and Plant Analysis, 12(1), 61-69.

Juliano, B. O. (1971). A simplified assay for milled rice amylose. Cereal Science. Today, 16, 334-360.

Kaushal, S., Karnwal, A., \& Yuvneet, R. (2013). Potential Plant Growth Promoting Activity of Rhizobacteria Pseudomonas sp in Oryza sativa. Journal National Production Plant Resources, 3 (4): 38-50.

Khush, G.S., Paule, C.M., \& Dela-Cruze, N. M. (1979). Rice grain quality evaluation and improvement at IRRI, Workshop on chemical aspects of rice grain quality. IRRI. Manila, Philippines.

Kumar, U., \& Dangar, T. K. (2013). Functional role of plant growth-promoting endo-and rhizobacteria in major cereal crops. Kheti, 1(1), 37-40.

Little, R. R. (1958). Differential effect of dilute alkali on 25 varieties of milled white rice. Cereal Chemistry, 35, 111-126.

Lugtenberg, B., Rozen, D. E., \& Kamilova, F. (2017). Wars between microbes on roots and fruits. F1000Research 6:343.

Mazid, M., \& Khan, T.A. (2017). Future of Bio-fertilizers in Indian agriculture: An Overview. Int J Agric Food Res.; 3(3),10-23.

Mckenzie, K. S., \& Ruther, J. N. (1983). Rice grain shape and rice grain quality. Crop Science, 23:306-313.

Mikael, B. B., Ghazy, H. A., Elekhtyar, N. M., \& Aziz, M. A. (2021). Using of bio and organic fertilization to reduce mineral nitrogen fertilizer and improve Sakha 108 rice cultivar productivity. Menoufia Journal of Plant Production, 6(1), 7182.

Mohammed, A. T. (2017). Production of high nutritional value cookies from broken rice supplemented with sweet lupin flour. Egyptain Journal of Agricultural Research, 95(2),755-767.

Oosterhuis, D. M., \& Weir, B. L. (2010). Foliar fertilization of cotton. In Physiology of cotton (pp. 272-288). Springer, Dordrecht.

Pan, S., Rasul, F., Li, W., Tian, H., Mo, Z., Duan, M., \& Tang, X. (2013). Roles of plant growth regulators on yield, grain qualities and antioxidant enzyme activities in super hybrid rice (Oryza sativa L.). Rice, 6(1), 1-10.

RRTC, (2020). Rice Research and Training Center (National Rice Research Program): Proceedings of the Rice Workshop, Annual Report, Sakha, Kafrelsheikh, Egypt.

Saadatnia, H., \& Riahi, H. (2009). Cyanobacteria from paddy fields in Iran as a biofertilizer in rice plants. Plant Soil and Environment 55(5), 207-212.

Singh, N., Kaur, L., Sodhi, N. S., \& Sekhon, K. S. (2005). Physicochemical, cooking and textural properties of milled rice from different Indian rice cultivars. Food Chemistry, 89(2), 253-259.

Sorour, S. G. R., Elekhtyar, N. M., El Rewainy, I. M., Ibrahim, M. H., \& Taha, H. A. (2018). Potential Use of Bio-Fertilizer and Stimulating Growth Compounds to Promote Rice Productivity. Journal of Plant Production, 9(6), 559-565.

Wissa, M. T., Awad-Allah, M. M. A., \& Elekhtyar, N. M. (2016). Response of Egyptian hybrid rice one cultivar to times of nitrogen application and foliar spraying of ascobien compound. Journal of Plant Production, 7(6), 567-574.

Wu, Q., Peng, X., Yang, M., Zhang, W., Dazzo, F. B., Uphoff, N., ... \& Shen, S. (2018). Rhizobia promote the growth of rice shoots by targeting cell signaling, division and expansion. Plant Molecular Biology, 97(6), 507-523.

Zidan, A. A., \& Elekhtyar, N. M. (2015). Response of two rice cultivars to bio and inorganic fertilization. Journal of Agricultural Research., Kafrelsheikh Univ, 41(3), 863-874.

Copyright: (C) 2022 by the authors. Licensee EAR, EKB, Egypt. EJAR offers immediate open access to its material on the grounds that making research accessible freely to the public facilitates a more global knowledge exchange. Users can read, download, copy, distribute, print or share a link to the complete text of the application under Creative Commons BY-NC-SA 4.0 International License. 


\title{
تأثير البكتيريا الجذرية المحفزة للنمو والسيانوبكتريا علي الصفات الفيزيائية والكيميائية وخصائص الميرة

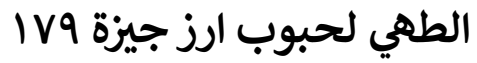

\author{
نهال محمد الاختيار * ومدوح محمد أحمد إبراهيم عوض الله و عبده عبد الله زيدان

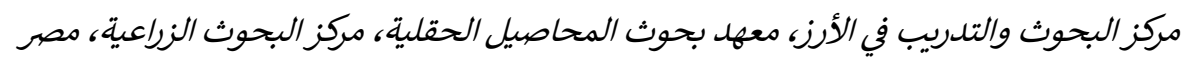 \\ بريد المؤلف المراسل: Orcid - Nehal RRTC@yahoo.com:
}

\section{الملخص الجودة الفير}

القيمة التسويقية لمنتج الأرز تعتمد في الغالب علي الجودة الفيزيائية والكيميائية وكفاءة خصائص الطبخ والأكل. الأرز

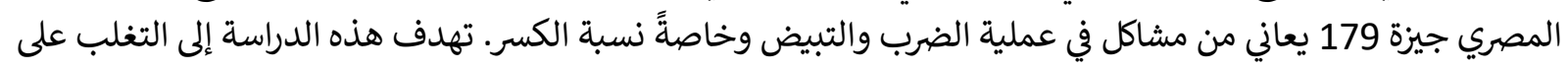

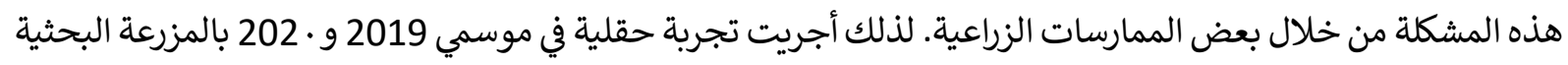

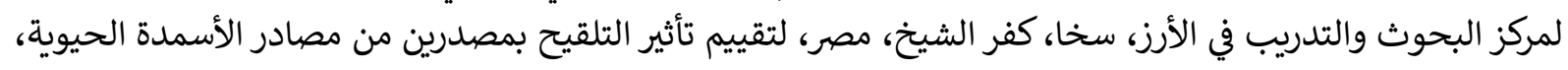

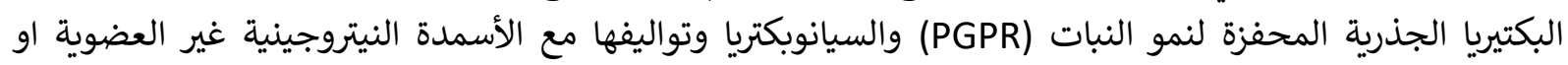

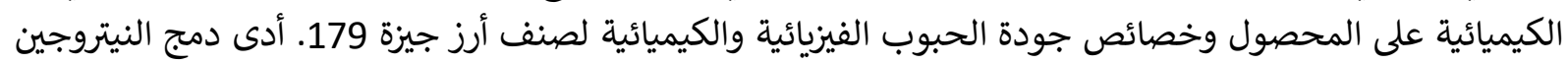

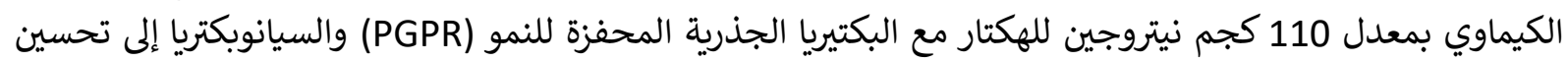

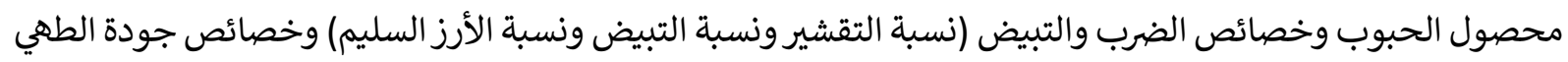

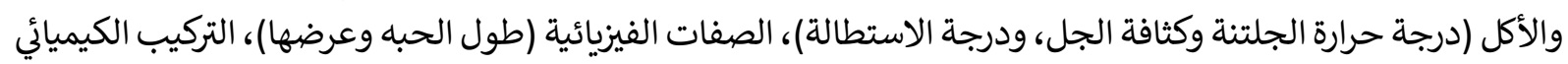

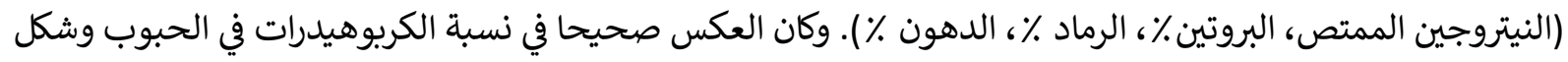

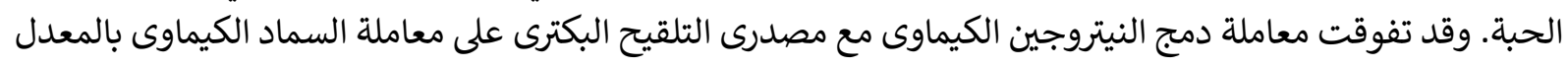

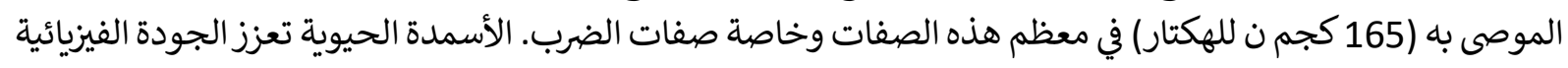

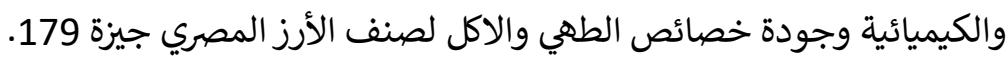

الكلمات المفتاحية: جودة حبوب الأرز, البكتريا الجذرية المحفزة للنمو, PGPR السيانوبكتريا,BGA,صنف الأرز المنزرع

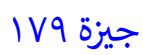

